\author{
Magdalena M. STUSS ${ }^{1}$ \\ Izabela STAŃCZYK \\ Anna WZIĄTEK-STAŚKO ${ }^{3}$
}

\title{
PROCESSES OF COMMUNICATION WITH CANDIDATES IN EMPLOYER BRANDING
}

\begin{abstract}
The employer branding concept has evolved from a novelty and solution originally addressed to large businesses to one of the tools used nowadays to build competitive advantage and oriented towards attracting the most talented candidates, as well as a method of limiting key employee fluctuation. Nowadays, the issue of employer branding is becoming increasingly important. More and more organizations realize that their future success may depend on whether they are able to attract, recruit and retain employees with the desired qualifications. The article discusses the concept of employer branding as a tool supporting the recruitment process within the framework of human resources management. Particular attention is external EB tools such as the Career / Work Tab on the potential employer's site. The key to effective use of the "career" tab is to ensure that the candidate is provided with relevant information to better understand the organization, assess whether the expectations of the employer and candidate are convergent, find an interesting job offer, and prepare for an interview. The results of research carried out among selected companies listed on the Warsaw Stock Exchange inclusion in WIG 30 on the content of the effectiveness of these websites were included. The companies representing three sectors (industry, finances, services) have been researched.
\end{abstract}

Keywords: employer branding, EB, communication, Career / Work Tab.

\footnotetext{
${ }^{1}$ Magdalena M. Stuss, PhD, Jagiellonian University, Institute of Economics, Finance and Management, Department of Organization and Management, Gołebia 24, 31-007 Krakow, Poland; e-mail: magdalena.stuss@uj.edu.pl (corresponding author).

Dr Magdalena M. Stuss, Uniwersytet Jagielloński, Katedra Organizacji i Zarządzania Instytut Ekonomii, Finansów i Zarządzania, ul. Gołębia 24, 31-007 Kraków; e-mail: magdalena.stuss@uj.edu.pl (autor korespondencyjny).

2 Izabela Stańczyk, PhD, Jagiellonian University, Institute of Economics, Finance and Management, Department of Human Resources Management, Gołebia 24, 31-007 Krakow, Poland; e-mail: izabela.stanczyk@uj.edu.pl

Dr Izabela Stańczyk, Uniwersytet Jagielloński, Katedra Zarządzania Zasobami Ludzkimi, Instytut Ekonomii, Finansów i Zarządzania, ul. Gołębia 24, 31-007 Kraków; e-mail: izabela.stanczyk@uj.edu.pl

3 Anna Wziątek-Staśko, DSc, PhD, Associate Prof., Jagiellonian University, Institute of Economics, Finance and Management, Department of Human Resources Management, Gołebia 24, 31-007 Krakow, Poland, e-mail: anna.wziatek-stasko@uj.edu.pl Dr hab. Anna Wziątek-Staśko, prof. UJ, Uniwersytet Jagielloński, Katedra Zarządzania Zasobami Ludzkimi, Instytut Ekonomi, Finansów i Zarządzania, ul. Gołębia 24, 31-007 Kraków; e-mail: anna.wziatek-stasko@uj.edu.pl
} 


\section{INTRODUCTION}

Today, more and more often the main source of knowledge about employers is the Internet. It will be more advantageous for the employer if the information about the candidate is found on the company website rather than on an internet forum that the company has no influence on. One of the most important factors that influence recruits decision of which company apply to is their perception of company brand ${ }^{4}$ CIPD research shows that for $75 \%$ of companies the employer branding helps with making recruitment process effective ${ }^{5}$. Hudson $^{6}$ reports shows that almost $63 \%$ of the 324 largest world businesses defined employer branding in their strategies and undertake activities related to this area. Research conducted in 2011 by Linkedin indicated point to that there are three reasons to develop good employer branding concept: spending less on hiring, boosting retention and influencing candidates decision ${ }^{7}$.

Studies show, $69 \%$ of Americans would not take a job with a company that had a bad reputation, even if they were unemployed and $84 \%$ would consider leaving their current jobs if offered another role with a company that had an excellent reputation (Employer Brand eBook). On the other hand Polish employers' greatest problem (38\%) is the continuously intensifying shortage of candidates for employment meeting requirements related to skills and competence. The research was conducted in the period from March to May 2016 by HRM Institute based on the CAWI method $^{8}$.

The companies cannot succeed if they don't attract relevant type of employees. The global talent pool companies is shrinking 9 . The objective of this paper is to present the preliminary results of the research employer branding - part: - used by companies listing on the Warsaw Stock Exchange. For stock exchange-listed companies, employer branding is the opportunity to reach potential candidates for employment. Companies cannot succeed if they don't attract relevant type of employees.

\section{EMPLOYER BRANDING, CARREER / WORK TAB - CONCEPTUAL ANALYSIS}

The employer branding concept has evolved from a novelty and solution originally addressed to large businesses to one of the tools used nowadays to build competitive advantage and oriented towards attracting the most talented candidates, as well as a method of limiting key employee fluctuation.

${ }^{4}$ D.B. Turban, D.M. Cable, Firm reputation and Aplicant Pool Characteristics, "Journal of Orgaizational Behavioure" 2003, Vol. 24, No. 6., p. 733-752.

5 K. Dyer, Employer Branding; A Vital Tool for Sucess, "Strategic Communication Management" 2007, Vol. 12, No. 1, p. 2.

${ }^{6}$ Hudson 2014: How to Launch a Successful Employer Brand: Building on the Practices of Top Employer Brands, 2014, www.hudson.sg (accessed: 22.03.2017).

${ }^{7}$ LinkedIn 2012: Employer Brand Playbook, https://snap.licdn.com (accessed 28.10.2016).

${ }^{8}$ K. Bilińska-Reformat, I. Stańczyk, Employer branding as a source of competitive advantage of retail chains, „Journal of Management and Business Administration. Central Europe” 2018, no. 1, p. 2-12.

9 A. Botha, M. Bussin, L.de Swartd, An employer branding predictive model for talent attraction and retention, "SA Journal of Human Resource Management" 2011, Vol 9, No 1, p. 1-12. 
Employer branding was first defined in 1996 by Barrow, who claimed that an employer brand was a package of functional, economic and psychological benefits provided by employment, and identified with the employing company ${ }^{10}$. A more detailed definition is provided by the Conference Board, which defines the concept as: 'the employer brand establishes the identity of the firm as an employer. It encompasses the firm's value system, policies and behaviours toward the objectives of attracting, motivating, and retaining the firm's current and potential employees' ${ }^{11}$. Sullivan ${ }^{12}$ demonstrated a similar approach assuming that 'employer brand is a targeted, long-term strategy to manage the awareness and perceptions of employees, potential employees, and related stakeholders with regards to a particular firm'. On the other hand, Backhous and Tikoo ${ }^{13}$ think that it is' a process of building an identifiable and unique identity of the employer', and that it expresses itself in the organizational identity and organizational culture (which it exerts influence upon one more time), and that it determines associations associated with the brand of the prospective employer and the loyalty of the employed personnel to the brand. Aggerholm and co-authors have offered a re-conceptualization of the employer brand concept as a holistic and processual discipline including the theoretical fields of branding, HRM and CSR' ${ }^{14}$. More contemporary definition presented by Sehgal and Malati (2013) translations employer branding like the image of an organisation that is perceived by stakeholders, shareholders and employees. It should show the uniqueness of the firm, allow to differentiate from competitors and encourage employees that the company is a good place to work at ${ }^{15}$.

In practice, employer branding is most frequently divided into external branding and internal branding. Internal employer branding is chiefly focused on creating a friendly work atmosphere and a possibility of development inside the organisation for employees. External employer branding may perform two functions: the image-creating function, aimed at increasing candidates' awareness of the brand, informing the labour market of the company and the advantages of working in it, presenting the competitive advantage or implementing the corporate social responsibility principles, and the recruitment-oriented function whose most important objective is finding the most appropriate candidates and persuading them to apply for the vacant positions ${ }^{16}$.

According to ManpowerGroup there are eight essential factors in developing effective employer branding strategy ${ }^{17}$ :

10 T. Ambler, S. Barrow, The Employer Brand, "Journal of Brand Management" 1996, Vol. 4, No. 3, p. 185-206.

${ }^{11}$ N. Ainspan, D. Dell, Engaging Employees through Your Brand, Conference Board 2001, p. 502.

12 J. Sullivan, Eight elements of a successful employment brand, ER Daily, 2004, No. 23 February.

${ }^{13} \mathrm{~K}$. Backhaus, S. Tikoo, Conceptualizing and researching employer branding, "Career Development International" 2004, Vol. 9, Nos No. 4/5, p. 501-517.

${ }^{14}$ H. Aggerholm, S. Andersen, C. Thomsen, Conceptualising employer branding in sustainable organisations, Corporate Communications, "An International Journal" 2011, Vol. 16, No. 2, p. $105-123$.

15 K.Sehgal, N.Malati: Employer Branding: A Potent Organizational Tool for Enhancing Competitive Advantage, The IUP Journal of Brand Management 2013, Vol. X, No. 1, March 2013, pp. 51-65.

${ }_{16}$ M. Kozłowski, Employer budowanie wizerunku pracodawcy krok po kroku, Warszawa 2012.

17 ManpowerGroup 2015: If You Build It, They Will Come: The New Role of Employer Brand, ManpowerGroup Solutions Recruitment Process Outsourcing, www.manpowergroup.com (accessed 28.11.2016). 
- Be Candidate Centric - company need to use marketing tools in their recruiting processes. They should use customized approaches that will engage applicants in ways they are not being engaged before. Company need to understand candidates' unique motivators, needs and life stages etc.

- Be Authentic - emotional connection with candidates is vital as separates one employer from another. Trust brand ambassadors with social media, don't try to influence their voice as contrived or forced messages as it will seem inauthentic and could harm good employer brand.

- Be consistent - the employer brand should have consistent tone and core values throughout the whole process. The objective and message should be clear to all parties that supporting the process to avoid "bait and switch" perception.

- Be informed - companies need to be aware of what is being said about them - good and bad - true and untrue as this create recruits perceptions about company. The company should continuously monitor and assess all the tools that are available like Twitter, LinkedIn, Facebook, Glassdoor, Get Rated! etc as they have real influence in the marketplace.

- Be creative - employers need to make sure that their job descriptions are up to date and reflect current trends on the market. They should reflect why the company is the best choice, why it is good to be employed by them and stay there. Companies should use innovative approaches such as employee ambassadors' videos of daily workplace activity or their testimonials. Company should have clear and efficient strategy how efficiently use Employment/Career/Work section of the company's website.

- Be proactive - company should continuously nurture talent communities before i needs to fill vacancies as this will allow company to secure real competitive advantage for attracting best talents when new position arise.

- Be reactive - if employer spot any negative reviews/opinion about the firm the issues arising should be follow up and then rectified. The positive reviews give an opportunity to provide deeper insight into company values and how it reinforces the EVP (Employee Value Proposition ).

- Be bold - employer reputation is increasingly being formed online often by factors the company have a little control over. So employers should be proactive and closely monitor marketplace dynamics.

In order to be successful, employer branding must contain each of essential elements. The most important is increasing candidate awareness of firm's best practices - the basic foundation of this step is to craft messages to organization's target audience of potential applicants, so that they apply for jobs specifically because of company's management and business practices ${ }^{18}$. So aaccording to Menor, some rule must be followed in order to attract and retain talented employees: Communication and availability - active listening to employee's and clear communication of expectations, goals and rules to be followed, give them honest feedback and helps them to feel recognized and important ${ }^{19}$.

18 J. Sullivan, Eight elements of a successful employment brand, ER Daily, 2004, No. 23 February.

19 J.H. Menor, 10 Strategic Tips for Employee Retention. 2010. The Recruiters Lounge, available at: http://www.therecruiterslounge.com/2010/08/17/10-strategic-tips-for-employee-retention/ (accessed 18.08.2017). 


\section{PROCESSES OF COMMUNICATION WITH CANDIDATES}

The emotional connection with candidates is more important than ever. It is what separates one employer from another among today's job seekers. Resist the impulse to attempt to control what brand ambassadors say and do on social media as a company might for public relations efforts. Savvy users of social networking sites can spot contrived or forced contributions that seem inauthentic. Such activity can actually do more harm than good to employer brand. The most successful HR professionals look at talent through the lens of marketers and apply marketing tools to their sourcing and recruiting processes. This appears to be especially important in attracting candidates who have been in the workforce for a long time. Taking into account passive candidates' unique motivators, needs and life stages, then customizing approaches/materials for them, will engage them in ways they are not being engaged now ${ }^{20}$.

Employer brand identity plays a vital role in attracting an individual towards employment. Hence, employer brand and its attractiveness greatly contributes towards the recruitment strategy of the organisation. Therefore, organisations should nurture, communicate and embed company reputation and employer brand ${ }^{21}$.

Impact of HR plans, processes and actions have significant impact on the employer branding process of any organization ${ }^{22}$. However HR practices like recruitment policies must align with the brand values to avoid conflicting messages ${ }^{23}$. In this manner, the organisation can use the good communication in giving the understanding to the employees about the employer brand and their role in strengthening the brand promise, henceforth reducing the confusion regarding the brand because of any misleading messages, if any. Rousseau ${ }^{24}$ asserts that if the subject of the brand message provides sufficient and clear information about the brand values, then it will help in improving the perception of the organisation.

Communication with a broad group of potential employees is of importance, both in order to improve the odds of attracting the right candidates as well as building brand awareness in the minds of a large audience for a long-term perspective ${ }^{25}$.

Research conducted by Bergman and Ärnström ${ }^{26}$ shows the communication has to be narrowed in order to come into closer contact with those more interested in and better suited

${ }^{20}$ ManpowerGroup 2015: If You Build It, They Will Come: The New Role of Employer Brand, ManpowerGroup Solutions Recruitment Process Outsourcing, www.manpowergroup.com (accessed 28.11.2016).

${ }^{21}$ C. Xie, R.P. Bagozzi, K.V. Meland, The impact of reputation and identity congruence on employer brand attractiveness, "Marketing Intelligence \& Planning" 2015, Vol. 33 Issue: 2, p. 124-146.

${ }^{22}$ T. Aurand, L. Gorchels, T. Bishop, Human resource management's role in internal branding: an opportunity for cross-functional brand message synergy, "The Journal of product and Brand Management" 2005, Vol. 14 Nos No. 2/3, p. 163-169.

${ }_{23}$ M. Gosti, A. Wilson, Corporate reputation management: living the brand, "Management Decision" 2001, Vol. 39 no. 2, p. 99-104.

${ }^{24}$ D. Rousseau: Schema, promise and mutuality: the building blocks of the psychological contract, Journal of Occupational and Organisational Psychology 2001, Vol. 74, pp. 511-541.

25 A. Parment, A. Dyhre, Sustainable Employer Branding: Guidelines, Worktools and Best Practices Paperback, Samfundslitteratur 2009.

26 J. Bergman, E. Ärnström, Attracting the right employees A study of successful employer branding, available at: http://citeseerx.ist.psu.edu/viewdoc/download?doi=10.1.1.468.2619\&rep=rep1\& type=pdf, (accessed: 18.08.2017). 
at working at the company. Finally once the target group has found the employer to be preferable the communication has to be on a more intimate level, even to the point of individual meetings. This process is not static, while the communication from the company focuses more narrowly, so does the potential employee's. A person who might have been initially attracted by the broad communication but still unsure as to whether or not the employer is the right one, might change this perspective during the process and ultimately view the employer as ideal. Research also show the following pattern for how employers choose to communicate. The three channels used to the highest percentage are: Career fairs, company websites and articles available online and in printed media. These are also the channels which this study focuses on, the last one widened to incorporate online presence in general.

Create a communication process for people to refer to, so everyone understands the different elements and knows how to consistently implement the brand across all of the different channels. It should always be authentic and proud of the organisation aspired to be. There's a big difference between 'we are' and 'we are aiming to be'. The employer brand needs to be 'genuine' and part of organisation's culture. After all, the attitude of people and the way they act is a key element of the employer brand. Organisations make sure recruitment processes are user friendly and employment experience is human, even if it's heavily automated.

With increased competition it has become imperative to attract, hire, develop and retain the best talent across the firms. Employers need to style themselves well to attract the attention and commitment of the brightest employees. One of the latest and most effective avenues for communicating employer brand is the use of social media.

Studies carried out in Poland have not confirmed the use of social media to collect data on future employers. Respondents pointed to traditional sources of such information on the Internet as websites, search engines or specialized portals related to professional careers and recruitment ${ }^{27}$.

Social media tools and social networking sites have revolutionized methods of communication both for professional and personal use. With an increase in number of people engaging in communication through social media, and also an increase in the number of HR professionals using social media to source candidates, it has become imperative to study the relevance of social media to the recruitment process. Employer branding via social media has also gained attention, and it has been recognized as the most promising medium ${ }^{28}$.

\section{CARREER / WORK TAB}

According to the research of the Polish Salary Service, Poles motivate high wages, good atmosphere in the workplace, competent superiors, sense of work and opportunities for development and training ${ }^{29}$. All of these aspects of the job can also encourage candidates to apply for a particular company - candidates must first know that it is for this particular employer to work. Career tab is a great, convenient and above all a low-cost way to inform

\footnotetext{
${ }^{27}$ M. Budzanowska-Drzewiecka, A. Lipińska, I. Stańczyk, Ocena działań podejmowanych przez pracodawców w zakresie zewnętrznego Employer Branding w Internecie z perspektywy osób poszukujacych pracy, „Zarządzanie i Finanse” 2013, No. 3, p. 91-105.

28 S. Mehta, S. Sharma, Usage of Social Media in Employee Sourcing and its Impact in Creating an Employer Brand, "Sumedha Journal of Management"; Hyderabad 2016, t. 5, Oct-Dec , p. 34-52.

${ }^{29}$ See more: www. wynagrodzenia.pl.
} 
your prospects about the benefits of working for your company. Employers have looked for information about:

- company values,

- opportunities for promotion,

- benefit, non-pay and social benefits

- remuneration.

By analyzing the placement of the career tab on the home page, it is clear that site designers do not always attach importance to this part - links to other pages are often placed outside the main menu area - such as at the bottom of the page, footer or other, less visible on the page. Very important from the point of view of profitability, the element of the subpage about the career should be recruiting ads. The cost of getting people to work is high, and the presence of current job offers increases the chance of getting applications from candidates who are really interested in the company.

In order for a candidate to feel that his or her candidature can meet with a positive response, he or she should be sure that the advert placed on the site is up to date. To be fully aware of the latest announcements, you will need the date of application or the information until you can submit your CV.

The recruitment process is also important for candidates. What does it look like? What do you expect? Does the company perform tests, the Assessment Center, recruits by head hunting, promotes recruiting by command? How much is waiting for the answer and whether the company responds to every application or just selected candidates? Such information builds trust in the company and makes the candidate feel respected by the prospective employer. It is extremely important if the company is going to build a positive image on the labor market. Recruiting Form is a method that allows a company to easily collect candidate data, which can normally be further exported through ERP systems to staff, if the candidate is employed. For a company it's a convenient solution, but it's not without a few pitfalls - firstly, investing in a recruiting system requires a lot of time spent by the HR department to create a tailor-made application for your business. These systems are also not cheap option. Secondly, the recruitment forms require the candidates to be involved and the time devoted to completing them. On the other hand, if a candidate completes the form ${ }^{30}$.

The detailed description of all the above levels makes applications only available to candidates who agree with the values of the company and for whom what the company offers is attractive enough - in the broader perspective, we reduce the cost of employment caused by the wrong recruitment decision (e.g. employing a candidate who is keen on such development opportunities that the company can not provide).

New technologies have given us tremendous opportunities for communication - social media is spreading the triumph of popularity around the world, Facebook has become more popular than Google, the biggest social media marketing potential. Western companies also discover the potential of this recruitment tool ${ }^{31}$.

${ }^{30}$ Raport kondycji stron „kariery” na stronach www największych pracodawców opracowany przez agencję marketingu zintegrowanego (A report on the condition of 'career' websites on the websites of the largest employers developed by the integrated marketing agency) GRUPA ADWEB, http://www.hrnews.pl/reports/strony_kariery_raport.pdf, (accessed: 18.08.2017).

31 Ibidem. 
The key to effective use of the "career" tab is to ensure that the candidate is provided with relevant information to better understand the organization, assess whether the expectations of the employer and candidate are convergent, find an interesting job offer, and prepare for an interview. The candidate, before making the decision to apply for the recruitment process, will certainly look first for information about the company and make sure he or she would like to obtain such an employer. Therefore, the information section of the bookmark should in particular be attractive. First of all, it is worthwhile to present here the organizational culture and values that guide the company. Secondly, in the career tab, the candidate should find out about the benefits and benefits available in the company, which will make it easier for him to make the decision. It is a good idea to allocate space for a description of the recruitment process in the company or its individual departments. Very often this part of the bookmark consists of three elements that in practice correspond to the different stages of the recruitment process: application selection, interviews and feedback. Familiarizing the candidate with this information will have a positive impact on his or her initial impressions and will facilitate preparation for contact with potential employers. The list of current job offers is an element that should be included in our booklet, and if you are running internship programs, it is also important to include information about them. It is also worth giving candidates the opportunity to submit so-called. spontaneous applications, ie those that do not respond to the published job advertisements published on the site. In addition to taking care of the relevant content of the bookmark career is worthwhile that the employer adapted this subpage for display on mobile devices. This solution makes it easy to contact candidates who are increasingly looking at mobile work opportunities. Effective targeting jobseekers requires appropriate, tailor-made tools that should take into account candidate experience and status, preferred ways of communicating with the environment, or living values ${ }^{32}$.

Transforming firm's employer brand across all areas of the organization won't be a walk in the park. But it will be very worthwhile. Firms should get the buy in of people at every level, across all areas of the organisation, so high level management and those on the frontline will get behind and know what they're doing and why automated ${ }^{33}$.

\section{METHODOLOGY AND RESEARCH RESULTS}

The adopted research strategy makes it possible to formulate the diagnosis of case studies, and afterwards to develop good practices for companies. The research tool was a multiple case study, which included a detailed description, followed by the validation of information accuracy, to increase the relevance of the test results. The case study method (the case study research was based upon the proposal of $\mathrm{Yin}^{34}$, made it possible to obtain information from numerous sources. Multiple cases augment external validity and help guard against observer biases. Moreover, multi-case sampling adds confidence to findings. By

\footnotetext{
32 A. Matuszewska, Employer Branding - nowy trend w obszarze HR [in:] E. Drop, M. Maćkiewicz, Młoda Psychologia, t. 1, Warszawa 2012, p. 438.

${ }^{33}$ How to Create a Powerful Employer Brand, Essential best practice and top tips for recruiters, available at: www.jobs.ac.uk/recruiters (accessed: 18.08.2017).

${ }^{34}$ R. Yin, Studium przypadku w badaniach naukowych. Projektowanie i metody, Kraków 2015, p. 49-51.
} 
looking at a range of similar and contrasting cases, we can understand a single-case finding, grounding it by specifying how and where and, if possible, why it behaves as it does ${ }^{35}$.

The researched companies have been carefully selected, so that it would be possible to apply both a literal replication (where results corroborate one another), as well as theoretical replication (where results differ, but for predictable reasons). The assumptions made it possible to conduct the collection of thoughtful and complete data because they originate from numerous sources and make triangulation possible. The diagnosed amount of case study replications is discretionary and does not constitute any rule. The screening of cases was performed upon the basis of the subjective assessment of the selected instances of the companies in the aspect of the similarity and competitiveness of them.

The research objective has been an analysis of external employer branding tools used by selected companies listed on the Warsaw Stock Exchange inclusion in WIG 30. WIG30 index has been published since $23^{\text {rd }}$ of September 2013 and represents the capitalization-of weighted stock market index based on the portfolio value of the 30 largest and most liquid companies listed on Warsaw Stock Exchange. The companies representing three sectors (industry, finances, services) have been researched. It has been assumed that, in each sector, up to three companies will be analysed (the article presents a fragment of the ongoing rese$\left.\operatorname{arch}^{36}\right)$. The selection is based on a sector-specific division of companies. Some enterprises conduct their business activities in many sectors, and thus they have been allocated to a particular category based on the dominant sector criterion. This approach will allow the determination of preliminary employer branding models for a researched area. The companies selected for the research have been listed on the main market of the Stock Exchange for at least 10 years and are not included in the Alert List. The list of alerts includes companies at risk of bankruptcy ${ }^{37}$.

The research focuses exclusively on carreer/work tab used in developing the employer's brand. The research process is based on public data, such as annual financial statements, quarterly financial statements, corporate social responsibility reports, corporate websites, trade unions' opinions, general reports on the position, brand and functioning of selected companies, as well as targeted interviews with company representatives.

The following research questions have criterias for evaluation:

- the web page bookmark career - its visibility and recognition,

- content in the tab,

- presentation style - amount of information, splitting, scrolling,

- description of the recruting process - process phase,

- possibility to apply online,

${ }^{35}$ M. Miles, A. Huberman, Qualitative data analysis, 2d ed. London 1994.

36 Supplementary employer branding research is presented in other articles (see: M. Stuss, Narzędzia employer branding $w$ praktyce wybranych banków, Zeszyty Naukowe WSZiB 2016 no. 40, http://zeszytnaukowy.pl; M. Stuss, Employer Branding - Nowe wyzwanie dla przedsiębiorstw (wyniki badań) [ in:] Zarządzanie przedsiębiorstwem. Analiza wspótczesnych uwarunkowań, koncepcji i determinant, ed. R. Borowiecki and T. Rojek, Kraków 2016; A. Herdan, M. Stuss, External Employer Branding Tools Used For Attracting Graduates By Enery Companies Listed At Warsaw Stock Exchange, Zeszyty Naukowe WSZiB 2017) and so far the external EB tools have been analysed in general in future.

37 Wskaźniki sektorowe, available at: https://www.gpw.pl/wskazniki_sektorow (accessed: 17.05. 2016). 
- how to provide feedback to candidates,

- use of social media.

Table 1 below presents the results of the research.

The following conclusions can be drawn from the conducted research:

- All companies have "Career/Job" Page as a Tab on the company homepage.

- All surveyed companies participate in job fairs, as they believe that this is the fastest and most effective communication channel with prospective applicants. They also regard job fairs as a great opportunity to create a database of prospective job applicants. Some companies prefers general fairs as other concentrate on specialise ones.

- Companies present a separate offer for people applying for internships or practical training (the Student Tab).

- All companies included in the sample try to attract prospective candidates by detailed information about available vacancies and additional benefits offered. They also offer on-line application process.

- The technical aspect of the websites is diversified; in the case of company 1 , the sites are modern, transparent and separated, but with insufficient multimedia and graphic materials; on the other hand, the technical aspect of the other company's website is perfect and consistent with labour markets' expectations.

- Companies have managed to avoid a major mistake of presenting obsolete information.

- Companies participate in job fairs, considering them to be the fastest and most effective communication channel and a possibility of expanding its job candidate database.

- In most companies there is no information on the further stages of recruitment.

- Inability to interview candidates in real time.

Table 1. Employer branding tools used Carreer / Work Tab

\begin{tabular}{|c|c|}
\hline Company 1 & Company 2 \\
\hline $\begin{array}{l}\text { - a direct link from the Work tab to the currently } \\
\text { vacant positions } \\
\text { - each offer comes with additional materials, i.e. } \\
\text { information concerning the position, require- } \\
\text { ments, scope of responsibilities, benefits } \\
\text { - an application form that can be sent on-line } \\
\text { - internships and practical training are not distin- } \\
\text { guished in the entire list of vacant positions } \\
\text { - the Work tab is on the home page but it is not } \\
\text { visible (it is hidden, one has to click the so-called } \\
\text { site map) } \\
\text { - two apparently similar tabs: the Work tab and the } \\
\text { Career tab are confusing } \\
\text { - no multimedia or graphic materials or modern } \\
\text { content has been included } \\
\text { - the Facebook, Twitter, Instagram, Youtube } \\
\text { accounts are up to date; a lot of information but } \\
\text { chiefly for company customers (product offers, } \\
\text { promotions, etc.) very little information for po- } \\
\text { tential candidates. }\end{array}$ & $\begin{array}{l}\text { - job offers are divided into those in the headquar- } \\
\text { ters and in branches } \\
\text { - an offer search engine with respect to divisions } \\
\text { and geographical regions } \\
\text { - a complete description of positions: main tasks, } \\
\text { expectations and benefits } \\
\text { - internships and practical training offers in the tab } \\
\text { for students } \\
\text { - an application form that can be sent on-line } \\
\text { - the Career tab is in the upper left part of the home } \\
\text { page, it is well visible } \\
\text { - a graphically rich and systematised description, } \\
\text { no excessive scrolling } \\
\text { - the Facebook account is up to date, with infor- } \\
\text { mation concerning vacant positions and com- } \\
\text { mencing recruitment processes (short notes in the } \\
\text { form of job advertisements) }\end{array}$ \\
\hline
\end{tabular}


Table 1 (cont.). Employer branding tools used Carreer / Work Tab

\begin{tabular}{|c|c|}
\hline Company 3 & Company 4 \\
\hline $\begin{array}{l}\text { - a direct link from the Career/Job tab to the cur- } \\
\text { rent vacancies } \\
\text { - each vacancies comes with detailed information } \\
\text { about criteria, benefits, development opportuni- } \\
\text { ties etc. } \\
\text { - a competition addressed to Polish graduates } \\
\text { wishing to pursue an internship in the company } \\
\text { - an application form that can be sent on-line } \\
\text { - www.pracuj.pl; Facebook; Youtube; LinkedIn }\end{array}$ & $\begin{array}{l}\text { - a direct link from the Career/Job tab to the cur- } \\
\text { rent vacancies } \\
\text { - each vacancies comes with detailed information } \\
\text { about criteria, benefits, development opportuni- } \\
\text { ties etc. } \\
\text { - } 3 \text { month paid summer internships in } 11 \text { business } \\
\text { areas } \\
\text { - tools for interview preparation (sample questions } \\
\text { and answers, checklists, tests) } \\
\text { - Facebook; Twitter; www.dnikariery.pl, but little } \\
\text { information for potential candidates }\end{array}$ \\
\hline Company 5 & Company 6 \\
\hline $\begin{array}{l}\text { - a direct link from the Career/Job tab to the cur- } \\
\text { rent vacancies } \\
\text { - each vacancies comes with detailed information } \\
\text { about criteria, benefits, development opportuni- } \\
\text { ties etc. } \\
\text { - summer internship } \\
\text { - Facebook; Twitter; Youtube; LinkedIn }\end{array}$ & $\begin{array}{l}\text { - direct link from the Career/Job tab to the current } \\
\text { vacancies } \\
\text { - each vacancies comes with detailed information } \\
\text { about criteria, benefits, development opportuni- } \\
\text { ties etc. } \\
\text { - Training Program } \\
\text { - Group Practice Program - run in cooperation } \\
\text { with schools and universities, opportunity to par- } \\
\text { ticipate in tasks using the latest technology under } \\
\text { the guidance of experienced specialists } \\
\text { - Dissertation support - assistance with conducting } \\
\text { a bachelor or master research project(thesis) } \\
\text { - an application form that can be sent on-line } \\
\text { - Facebook, LinkedIn, which focus exclusively on } \\
\text { job postings, lack of data for professionals or } \\
\text { managers }\end{array}$ \\
\hline Company 7 & Company 8 \\
\hline $\begin{array}{l}\text { - direct link from the Career/Job tab to the current } \\
\text { vacancies } \\
\text { - each vacancies comes with detailed information } \\
\text { about criteria, benefits, development opportuni- } \\
\text { ties etc. } \\
\text { - Internship - useful information on how to apply } \\
\text { - Talent Mine - the program address to final year } \\
\text { students and recent graduates offers unique } \\
\text { opportunity to work for one of the world's largest } \\
\text { mining companies: rotation in various areas of } \\
\text { the company (including international offices) } \\
\text { - Youtube; LinkedIn, no Facebook what astonish- } \\
\text { ing }\end{array}$ & $\begin{array}{l}\text { - direct link from the Career/Job tab to the current } \\
\text { vacancies } \\
\text { - each vacancies comes with detailed information } \\
\text { about criteria, benefits, development opportuni- } \\
\text { ties etc. } \\
\text { - "Energy for the Future" training program for stu- } \\
\text { dents of the final year and recent graduates } \\
\text { - Academy of Capital Market Leaders - the best } \\
\text { participants of the Academy have the opportunity } \\
\text { to take paid internships at the } \\
\text { - WE BUILD THE VALUE OF THE POLISH } \\
\text { ECONOMY. WORK FOR US! - an internship } \\
\text { program for graduates supported by Ministry of } \\
\text { Treasury, addressed to the best master engineer- } \\
\text { ing students, offers internships to gain experience } \\
\text { in the most interesting projects } \\
\text { - an application form that can be sent on-line } \\
\text { - Facebook; Instagram; LinkedIn }\end{array}$ \\
\hline
\end{tabular}

Source: own work. 


\section{CONCLUSION}

Summing up, the conducted research indicates that the basic external employer branding tools used by the examined companies are websites with a Career/ Work tab and participation in job fairs. The remaining areas are just being identified and tested with respect to their effectiveness in employer branding or they remain completely unknown as yet.

The professional side of the career has an attractive, attractive, trustworthy look, as well as updated, interestingly presented information. Organizations, in addition to posting current job offers, often include information on the value of the company, guidance on interview preparation, and the description of the recruitment process. It is worth noting that bookmarks for careers often also include sections for students and / or graduates, which describe opportunities for earning professional experience such as internships, placements or development programs. This fact may indicate that this target group is an important environment for employers, hence the formula for placing content specifically targeted to that particular group. Furthermore, the separation of messages intended for students and graduates may also be an attempt at matching the content and form of the message to the specific audience.

A career site as the primary source of knowledge about employers is appreciating more and more job seekers. When attractive, it effectively attracts candidates. When it is archaic and expressionless, it has as little information as effectively discouraging and discouraging it. The worst is when the candidate does not find anything on it except the message "At the moment we do not have any job offers".

Nowadays, the issue of employer branding is becoming increasingly important. More and more organizations realize that their future success may depend on whether they are able to attract, recruit and retain employees with the desired qualifications.

\section{REFERENCES}

1. 10 Must-Haves for Your Employer, Employer Brand eBook, Glassdoor (accessed: 18 August 2017).

2. Aggerholm H., Andersen S., Thomsen C., Conceptualising employer branding in sustainable organisations, Corporate Communications: An International Journal 2011, Vol. 16 No. 2.

3. Ainspan N., Dell D., Engaging Employees through Your Brand, Conference Board 2001.

4. Ambler T., Barrow S., The Employer Brand, "Journal of Brand Management" 1996, Vol. 4, No. 3.

5. Aurand T., Gorchels L., Bishop T., Human resource management's role in internal branding: an opportunity for cross-functional brand message synergy, "The Journal of product and Brand Management" 2005, Vol. 14 No. 2/3.

6. Backhaus K.,Tikoo S., Conceptualizing and researching employer branding, "Career Development International" 2004, Vol. 9, No. 4/5.

7. Bilińska-Reformat K., Stańczyk I., Employer Branding as a Source of Competitive Advantage of Retail Chains, „Journal of Management and Business Administration. Central Europe” 2018, No.1.

8. Botha A., Bussin M., de Swartd L., An employer branding predictive model for talent attraction and retention, "SA Journal of Human Resource Management" 2011, Vol 9, No. 1. 
9. Budzanowska-Drzewiecka M., Lipińska A., Stańczyk I., Ocena działań podejmowanych przez pracodawców w zakresie zewnętrznego Employer Branding $w$ Internecie z perspektywy osób poszukujących pracy, „Zarządzanie i Finanse” 2013, No. 3.

10. Dyer K., Employer Branding; A Vital Tool for Sucess, "Strategic Communication Management" 2007, Vol. 12, No. 1.

11. Gosti M.,Wilson A., Corporate reputation management: living the brand, "Management Decision" 2001, Vol. 39 No. 2.

12. Herdan A., Stuss M., External Employer Branding Tools Used For Attracting Graduates By Enery Companies Listed At Warsaw Stock Exchange, Zeszyty Naukowe WSZiB 2017.

13. Kozłowski M., Employer budowanie wizerunku pracodawcy krok po kroku, Wolters Kluwer Business, Warszawa 2012.

14. Kuar P., Sharma S., Kaur J., Sharma K., Using Social Media for Employer Branding and Talent Management, An Experimental Study, "The IUP Journal of Brand Management" 2015, Vol. XII, No. 2.

15. Kumar Dawn S., Biswas S., Employer branding: A new strategic dimension of Indian corporations, Asian Journal Of Management Research” 2010.

16. Matuszewska A., Employer Branding - nowy trend w obszarze HR, in: Drop E., Maćkiewicz M., Młoda Psychologia, T. 1.,Liberi Libri, Warszawa 2012, p. 438.

17. Mehta S., Sharma S.: Usage of Social Media in Employee Sourcing and its Impact in Creating an Employer Brand, Sumedha Journal of Management; Hyderabad 2016 Tom 5, Oct-Dec, pp. 34-52.

18. Miles M., Huberman A., Qualitative data analysis. 2d ed. London: Sage 1994.

19. Parment A., Dyhre A., Sustainable Employer Branding: Guidelines, Worktools and Best Practices Paperback, Samfundslitteratur 2009.

20. Rousseau D., Schema, promise and mutuality: the building blocks of the psychological contract, "Journal of Occupational and Organisational Psychology" 2001, Vol. 74.

21. Shah M., Talent retention through Employer Branding, "Journal of Marketing \& Communication" 2011, January-April, Vol. 6, Issue 3.

22. Sehgal K., Malati N., Employer Branding: A Potent Organizational Tool for Enhancing Competitive Advantage, "The IUP Journal of Brand Management" 2013, Vol. X, No. 1, March 2013.

23. Simmons J.A., "Both sides now”: aligning external and internal branding for a socially responsible era, "Marketing Intelligence \& Planning" 2009, Vol. 27, Issue: 5.

24. Stuss M., Narzędzia employer branding $w$ praktyce wybranych banków, Zeszyty Naukowe WSZiB 2016 no. 40, http://zeszytnaukowy.pl

25. Stuss M., Employer Branding - Nowe wyzwanie dla przedsiębiorstw (wyniki badań) [in:] Zarządzanie przedsiębiorstwem. Analiza wspótczesnych uwarunkowań, koncepcji i determinant, ed. R. Borowiecki and T. Rojek, Wydawnictwo Fundacja UEK, Kraków 2016.

26. Sullivan J., Eight elements of a successful employment brand, ER Daily, 2004, No. 23 February.

27. Turban D.B., Cable D.M., Firm reputation and Aplicant Pool Characteristics, "Journal of Orgaizational Behavioure" 2003, Vol. 24, No. 6.

28. Wheeler A.R., Richey R.G., Tokkman M., Sablynski C.J., Retaining Employees for Service Competencies; The Role of Corporate Brand Identity, "Journal of Brand Management" 2006, Vol. 14, No. 1\&2.

29. Willock R., Employer branding is key to fight talent, Personnel Today, May 2005. 
30. Xie C., Bagozzi R.P., Meland K.V., The impact of reputation and identity congruence on employer brand attractiveness, "Marketing Intelligence \& Planning” 2015, Vol. 33, Issue 2.

31. Yin R., Studium przypadku w badaniach naukowych. Projektowanie i metody, Wydawnictwo Uniwersytetu Jagiellońskiego, Kraków 2015.

\section{INTERNET SOURCES}

1. Bergman J., Ärnström E., Attracting the right employees A study of successful employer branding, available at: http://citeseerx.ist.psu.edu/viewdoc/download?doi=10.1.1.468. 2619\&rep=rep1\&type=pdf (accessed: 18.08.2017).

2. How to Create a Powerful Employer Brand, Essential best practice and top tips for recruiters, available at: www.jobs.ac.uk/recruiters (accessed: 18.08.2017).

3. Hudson 2014: How to Launch a Successful Employer Brand: Building on the Practices of Top Employer Brands, 2014, www.hudson.sg (accessed: 22.03.2017).

4. If You Build It, They Will Come: The New Role of Employer Brand, ManpowerGroup Solutions Recruitment Process Outsourcing (2015), available at: www.manpowergroup. com (accessed: 28 November 2016).

5. LinkedIn 2012: Employer Brand Playbook, https://snap.licdn.com (accessed 28.10.2016).

6. ManpowerGroup 2015: If You Build It, They Will Come: The New Role of Employer Brand, ManpowerGroup Solutions Recruitment Process Outsourcing, www.manpowergroup.com (accessed 28.11.2016).

7. Menor, J. H.: 10 Strategic Tips for Employee Retention. 2010. The Recruiters Lounge, available at: http://www.therecruiterslounge.com/2010/08/17/10-strategic-tips-for-employee-retention/ (accessed 18.08.2017).

8. Raport kondycji stron „kariery” na stronach www największych pracodawców opracowany przez agencję marketingu zintegrowanego GRUPA ADWEB, http://www.hrnews.pl/reports/strony_kariery_raport.pdf, (accessed: 18.08.2017).

9. Wskaźniki sektorowe, available at: https://www.gpw.pl/wskazniki_sektorow (accessed: 17.05.2016).

10. wynagrodzenia.pl (accessed: 18.08.2017).

\section{PROCESY KOMUNIKACJI Z KANDYDATAMI W RAMACH EMPLOYER BRANDING}

Koncepcja employer brandingu ewoluowała od narzędzia skierowanego pierwotnie do dużych przedsiębiorstw, aż do standardu wykorzystywanego obecnie do budowania przewagi konkurencyjnej i ukierunkowanego na przyciąganie najbardziej utalentowanych kandydatów, a także metody służącej ograniczaniu fluktuacji kluczowych pracowników. W dzisiejszych czasach coraz ważniejsze staje się zagadnienie employer brandingu. Coraz więcej organizacji zdaje sobie sprawę, że ich przyszły sukces może zależeć od tego, czy są w stanie przyciągać, rekrutować i zatrzymywać pracowników o pożądanych kwalifikacjach.

$\mathrm{W}$ artykule omówiono koncepcję employer brandingu jako narzędzia wspierającego proces rekrutacji w ramach zarządzania zasobami ludzkimi. Szczególną uwagę należy zwrócić na zewnętrzne narzędzia EB, takie jak zakładka Kariera / Praca na stronie potencjalnego praco- 
dawcy. Kluczem do efektywnego wykorzystania zakładki „kariera” jest zapewnienie kandydatom odpowiednich informacji, które pozwolą lepiej zrozumieć organizację, ocenić czy oczekiwania pracodawcy i kandydata są zbieżne, znaleźć interesującą ofertę pracy i przygotować się do rozmowy kwalifikacyjnej. W artykule omówiono koncepcję employer brandingu jako narzędzia wspierającego proces rekrutacji w ramach zarządzania zasobami ludzkimi. Zaprezentowano wyniki badań przeprowadzonych wśród wybranych spółek notowanych na Giełdzie Papierów Wartościowych w Warszawie należących do indeksu WIG 30 w zakresie skuteczności powyższych narzędzi. Zbadano przedsiębiorstwa reprezentujące trzy sektory (przemysł, finanse, usługi).

Słowa kluczowe: employer branding, EB, komunikacja, zakładka Kariera / Praca.

DOI: $10.7862 / \mathrm{rz} .2018 . \mathrm{mmr} .55$

Tekst ztożono do redakcji: listopad $2018 \mathrm{r}$.

Tekst przyjęto do druku: grudzień 2018 r. 
